\title{
Formulation and evaluation of lansoprazole sublingual tablet
}

\author{
Vishal SHELKE 1 * iD, Swati MUTHA 1 iD \\ 1 Department of Pharmaceutics, Seth Govind Raghunath Sable College of Pharmacy, Saswad, Dist - Pune, \\ Maharashtra, INDIA. \\ * Corresponding Author. E-mail: vishal.dshelke1653@gmail.com (V.S.); Tel. +91-211-522 2212.
}

Received: 15 June 2019 / Revised: 03 February 2020/ Accepted: 14 February 2020

\begin{abstract}
The objectives of present investigation is to improve the solubility and rate of dissolution of poorly aqueous soluble drug lansoprazole by preparing solid dispersion with amphiphilic carrier Soluplus in 1:2 concentration by using solvent evaporation method, solvent melting method and microwave oven method and selecting the best solid dispersion. The drug and excipient compatibility study of selected solid dispersion was performed by FTIR and DSC. These study showed no interaction in drug and carrier. The sublingual tablet represents an innovative drug delivery system, sublingual tablet of lansoprazole was formulated by incorporating selected solid dispersion with combination of novel superdisintegrants and taste maskers like Indion - 414 and Kyron $\mathrm{T}-314$ by using direct compression method. The sublingual tablet showed the rapid disintegration within average 32 seconds. All the evaluations were performed and complies with the pharmacopoeial standards. The drug and excipient compatibility study of lansoprazole sublingual tablet was also performed by FTIR and DSC. These study showed no interaction in drug and excipients. The formulation F9 (12\% superdisintegrants) showed $98.42 \%$ of cumulative drug release within $8 \mathrm{~min}$ with zero order release pattern. These novel formulation lansoprazole sublingual tablet showed quick on set of action and may be found to be beneficial, convenient for pediatrics, geriatrics, and psychiatric patients and patients with swallowing difficulties and in situations where water is not available.
\end{abstract}

KEYWORDS: Lansoprazole; sublingual tablet; indion-414; kyron-314; solvent melting.

\section{INTRODUCTION}

Lansoprazole belongs to the group of antisecretory compounds i.e proton pump inhibitor which blocks the closing step in acid production by inhibiting the enzyme system $\mathrm{H}+/ \mathrm{K}+$ ATPase called proton pump on the uppermost layer of the gastric parietal cell [1,2]. It comes under the BCS class II classification, have less aqueous solubility and high permeability. Its oral bioavailability is $85 \%$ and biological half life is 1.5 hours. Lansoprazole is safe and effective for the treatment option or symptomatic relief for disorders related to acid like Gastroesophageal reflux disease (GERD), Zollinger-Ellison syndrome, Peptic ulcer, lesions produced by Non steroidal antiinflammatory drugs (NSAIDS), also it is effectively used in combination with distinct regimens for $\mathrm{H}$. pylori eradication [3-6].

Now a days, there is need for developing more patient favourable and comfortable dosage forms. The sublingual route within the mouth cavity is attractive site for delivery of drug due to ease of administration, low cost manufacturing and dose accuracy [7]. Sublingual means "under the tongue", the sublingual tablet is administered in such way that it gets rapidly disintegrate, dissolve in patient's mouth without chewing or water administration and absorbed rapidly through the blood vessels present below the tongue. Therefore the drug gets enter into systemic circulation to give on set of action by avoiding the first pass metabolism and degradation [8-10]. This route is most suitable for acid labile drugs and convenient for paediatrics, geriatrics, and psychiatric patients and also patients with difficulties in swallowing (dysphagia), and in situations where water is not available [11].

As per market survey, lansoprazole is available as enteric coated pellets, filled in capsule as it is acid labile. An enteric coating can delay the release of drug but this process is tedious and costly [12]. Therefore here attempts are made to prepare the sublingual tablet of lansoprazole after improving its solubility by solid dispersion method. 
As lansoprazole have a low aqueous solubility, it can be increased by preparing solid dispersion with amphiphilic carrier. Solid dispersion is a process in which active ingredients are dispersed in amphiphilic matrix, to increase the aqueous solubility of poorly soluble drug [13].

The purpose of this research work is to enhance the lansoprazole solubility by preparing solid dispersion with different methods of preparation using amphiphilic carrier and then formulating sublingual tablet by incorporating the best, suitable concentration of solid dispersion and superdisintegrants.

\section{RESULTS AND DISCUSSION}

\subsection{Calibration curve of lansoprazole in methanol}

The UV spectroscopy method was selected as an analytical tool for lansoprazole to calculate the solubility data and percent (\%) release data of prepared formulation. Calibration curve of lansoprazole in acidic media do not showed linearity for this reason calibration curve of lansoprazole in methanol was developed at $284 \mathrm{~nm}$ and it showed good linearity. The calibration curve's linear regression equation and correlation coefficient was found to be $\mathrm{y}=0.0401 \mathrm{x}+0.0047$ and $\mathrm{R}^{2}=0.9967$. Calibration curve of lansoprazole depicted in Figure 1.

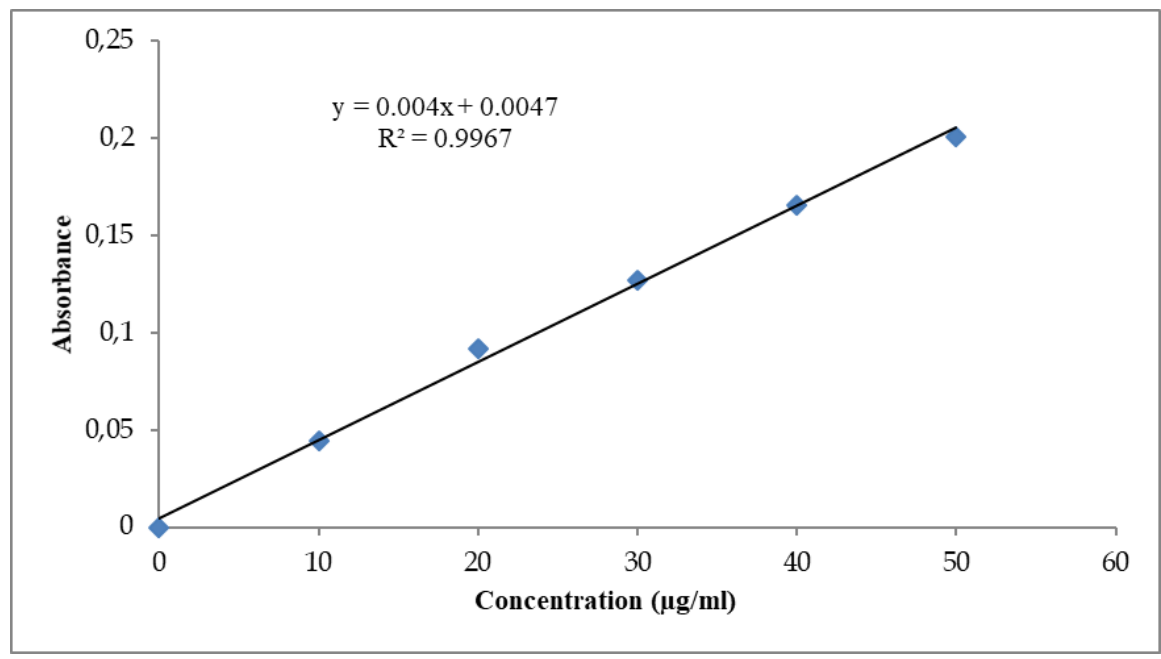

Figure 1. Calibration curve of Lansoprazole in methanol.

\subsection{Solubility study of lansoprazole}

Lansoprazole showed higher solubility in acidic media as compared to neutral or alkaline media. Solubility and stability are $\mathrm{pH}$ dependent, lansoprazole is soluble in acidic $\mathrm{pH}$ but had a stability issue and solution form of drug have less stability than solid form. The highest solubility is observed in the phosphate buffer $\mathrm{pH} 6.8[14,15]$. This data primarily indicate suitability of lansoprazole for sublingual route as saliva have a $\mathrm{pH}$ range 6.2 to 7.6. The solubility of each dissolution medium are shown in Table 1.

Table 1. Solubility study of lansoprazole.

\begin{tabular}{ccc}
\hline Sr. No & Medium & Solubility $(\mathbf{m g} / \mathbf{m l})$ \\
\hline 1 & Distilled water & $0.022 \pm 0.14$ \\
2 & Phosphate buffer $\mathrm{pH} 6.8$ & $0.072 \pm 0.11$ \\
3 & Phosphate buffer $\mathrm{pH} 7.2$ & $0.042 \pm 0.12$ \\
4 & $0.1 \mathrm{~N} \mathrm{HCL}$ & $0.063 \pm 0.10$ \\
\hline a All values represents mean \pm SD $(\mathrm{n}=3)$. &
\end{tabular}

\subsection{Preparation of lansoprazole solid dispersions}

The solid dispersions of lansoprazole were prepared with 1:2 concentration of lansoprazole and amphiphilic carrier Soluplus by using different methods like solvent evaporation method, solvent melting method and microwave oven method are shown in Table 2. 


\subsection{Solubility determination of lansoprazole solid dispersion}

Solubility determination of the lansoprazole solid dispersion was carried out by Higuchi and Connors method mentioned in section 4.4 [15]. The solubility data of lansoprazole solid dispersion revealed that, all the solid dipsersions showed enhanced solubility. Composition of various lansoprazole solid dispersions with methods, concentration and solubility study are shown in Table 2.

Table 2. Composition of various lansoprazole solid dispersions with methods, concentration and solubility study.

\begin{tabular}{|c|c|c|c|c|}
\hline Sr. No & Method & Ingredients & Ratio & $\begin{array}{c}\text { Solubility } \\
(\mathrm{mg} / \mathrm{ml})\end{array}$ \\
\hline 1 & $\begin{array}{c}\text { Solvent } \\
\text { Evaporation } \\
\text { Method }\end{array}$ & $\begin{array}{c}\text { Lansoprazole + } \\
\text { Soluplus }\end{array}$ & $1: 2$ & $0.82 \pm 0.12$ \\
\hline 2 & $\begin{array}{l}\text { Solvent Melting } \\
\text { Method }\end{array}$ & $\begin{array}{c}\text { Lansoprazole }+ \\
\text { Soluplus }\end{array}$ & $1: 2$ & $0.93 \pm 0.09$ \\
\hline 3 & $\begin{array}{c}\text { Microwave Oven } \\
\text { Method }\end{array}$ & $\begin{array}{c}\text { Lansoprazole }+ \\
\text { Soluplus }\end{array}$ & $1: 2$ & $0.77 \pm 0.17$ \\
\hline
\end{tabular}

a All values represents mean $\pm S D(n=3)$.

The lansoprazole solid dispersion prepared with amphiphilic carrier Soluplus by solvent melting method showed enhanced solubility $(1: 2) 0.93 \mathrm{mg} / \mathrm{ml}$ when compared to the solubility by all the method and pure drug in phosphate buffer $\mathrm{pH}$ 6.8. Soluplus is a combination of polyethylene glycol, polyvinyl acetate and polyvinylcaprolactame ( PEG, PVAc, PVCap) based graft polymer has a amphiphilic nature. Due to amphiphilic nature of Soluplus gives action of micellar solubilization to the drug. The Soluplus forms the large micelles which entrap the drug molecule and also forms the smaller particles gives increased surface area in solid dispersion enhances the solubility of drug. Soluplus forms the micelles because of the hydrophilic part polyethylene glycol and lipophilic part vinyl caprolactam/vinyl acetate are present in its structure which gives the amphiphilicity required for formation of micelles in the water. Thus minimum amount of the amphiphilic carrier gives marked improvement in the solubility of the drug is achieved without altering the material properties of the drug. Lansoprazole solid dispersion prepared with amphiphilic carrier Soluplus by solvent melting method with 1:2 concentration was selected for preparation of sublingual tablet.

\subsection{Characterization of lansoprazole solid dispersion}

The FTIR of pure lansoprazole showed the functional groups bands are $1643.41 \mathrm{~cm}^{-1}$ ( $\mathrm{C}=\mathrm{C}$ Alkene), $3171.08 \mathrm{~cm}^{-1}$ (N-H stretching), $3410.26 \mathrm{~cm}^{-1}$ (N-H 2 ${ }^{\circ}$ amine), $1242.20 \mathrm{~cm}^{-1}$ (Fluorine), $1589.40 \mathrm{~cm}^{-1}$ (C=C aromatic), $1064.89 \mathrm{~cm}^{-1}$ (S=O stetching) [16] and DSC thermogram of pure lansoprazole showed the endothermic peak melting at $180.55^{\circ} \mathrm{C}$ indicates the crystalline nature of lansoprazole and exothermic peak at $181.94^{\circ} \mathrm{C}$ because of the decomposition of lansoprazole [17]. The FTIR spectra of pure lansoprazole are depicted in Figure 2 and DSC of pure lansoprazole are depicted in Figure 3.

From the different solid dispersion the one was selected on the basis of solubility and characterized for drug and carrier compatibility by FTIR \& DSC. The FTIR of lansoprazole Soluplus solid dispersion not showed sharp peak because of the mixture of solid dispersion is in amorphous state or drug are miscible with the carrier matrix. Also the FTIR spectra revealed that formation of hydrogen bonds which might be atributing enhanced dissolution of drug.

The DSC thermogram of selected lansoprazole solid dispersion was clearly indicated amorphisation of the drug. The DSC thermogram of lansoprazole Soluplus solid dispersion showed two endothermic peak, first peak is at $59.74^{\circ} \mathrm{C}$ indicates the melting point of Soluplus, second peak is at $163.66^{\circ} \mathrm{C}$ indicates peak are broad and shifted to a lower temperature and exothermic peak of drug are disappeared as compared to pure drug peak indicates complete miscibility of drug in a molten carrier or the absence of crystalline form of lansoprazole, means mixture is in amorphous state and indicates no degradation of drug in solid dispersion. Thus there was formation of homegeneous molecular dispersion of drug in a matrix of Soluplus. Due to the thermodynamic instability of amorphous solids, compared to the crystalline state, spontaneous crystallisation is always possible as soon as molecular mobility is above the threshold of nucleation, these was because of heating effect takes place at molecular level which is responsible for molecular mobility. 
However the melting peak of Soluplus in solid dispersion (SD) was observed at $59.74^{\circ} \mathrm{C}$. The data suggest that SDs improve the drug dissolution by particle size reduction or due to wetting. The FTIR spectra of selected lansoprazole solid dispersion are depicted in Figure 2 and DSC thermogram of selected lansoprazole solid dispersion are depicted in Figure 3.

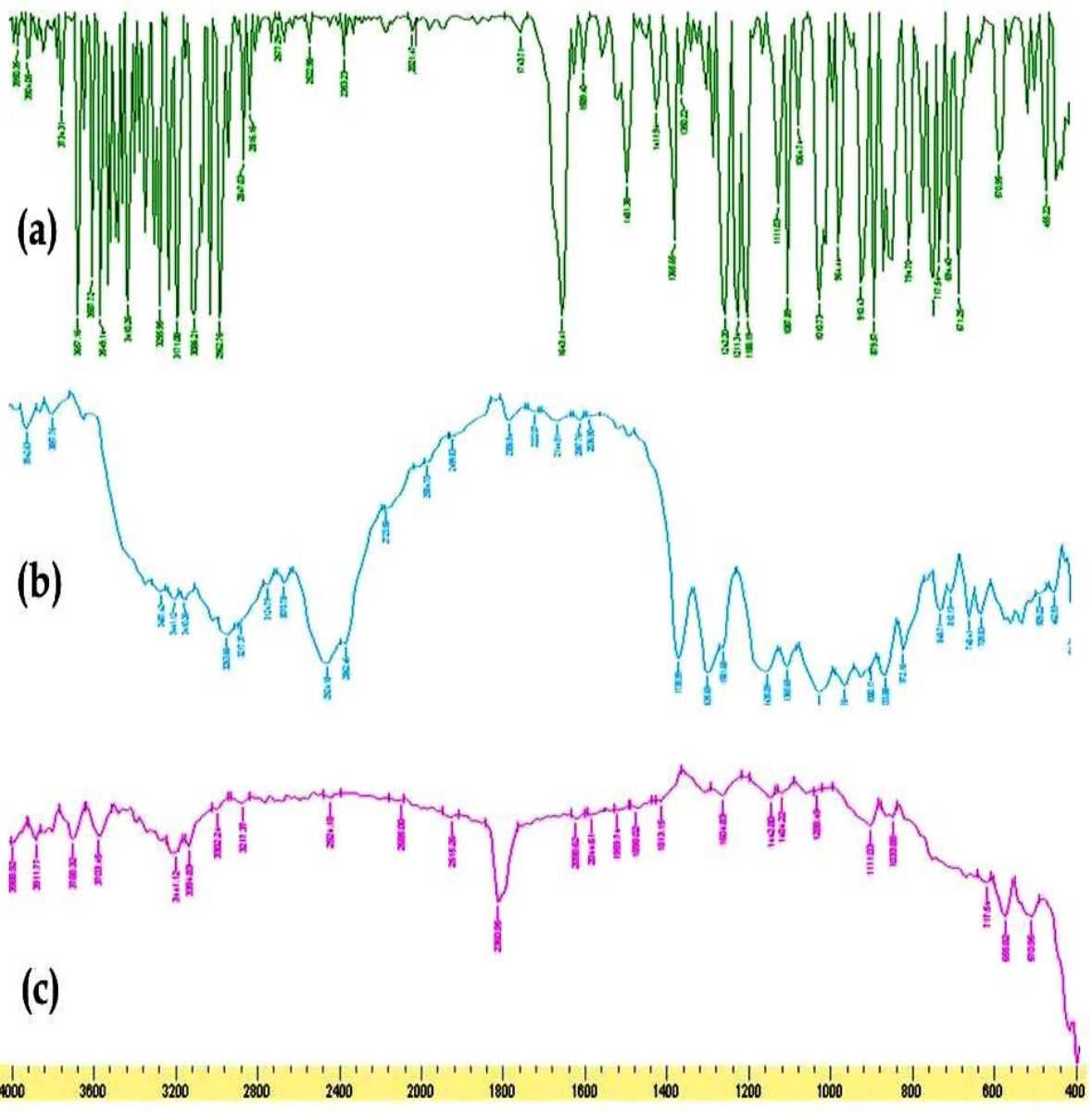

Figure 2. FTIR spectra of (a) Pure lansoprazole, (b) Selected lansoprazole solid dispersion, (c) Lansoprazole sublingual tablet F9.

\subsection{Formulation and evaluation of sublingual tablet of lansoprazole solid dispersion}

The solid dispersion of lansoprazole prepared by solvent melting method with Soluplus in 1:2 concentration was selected for sublingual tablet. In the formulation of powder blend of lansoprazole sublingual tablet Indion - 414 with Kyron T - 314 were used as superdisintegrants and taste masking agents. Avicel pH 102 (MCC) as binder, magnesium stearate as lubricant, talc as glidant, sodium saccharin as sweetener. The formulation batches are shown in Table 3.

In the literature review, it was found that combination of Indion - 414 and Kyron T - 314 was superior to the individual entity as superdisintegrants [18]. These superdisintegrants are weak acid cation exchange resins have a high water uptake capacity and when contact with water it swells rapidly due to which adhesion between the other tablet ingredients are removed causing the tablet to disintegrate [19].

The formulations were done with different concentration as $4,6,8,10,12 \%$ of superdisintegrants to study the effect of concentration of superdisintegrants on disintegration time. All the tablet formed are with a buff color and good appearance. These tablets were further evaluated for disintegration time. Disintegration time is a major consideration for sublingual tablet. According to USP the disintegration time for subligual tablet is less than 2 minute is acceptable [20]. Reduction in the disintegration time is a added advantage of formulation for maximum absorption and compliance by the patient. It was found that increase in the superdisintegrant concentration from 4 to $8 \%$ enhanced the reduction in disintegration time from 66 to 52 seconds as observed in formulation F1 to F3 having $20 \%$ avicel as binding agent. 
(a)
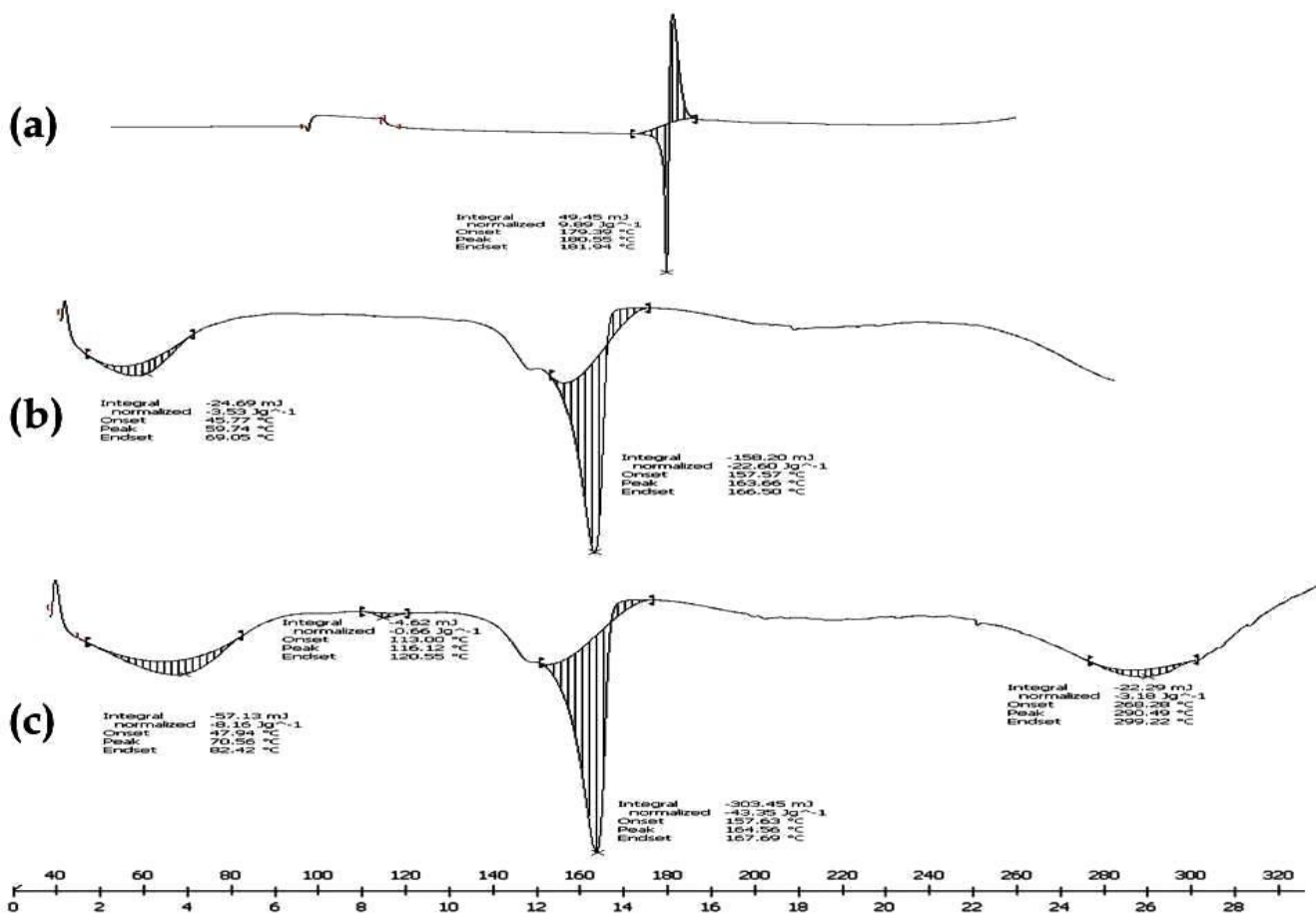

Figure 3. DSC thermogram of (a) Pure lansoprazole, (b) Lansoprazole solid dispersion, (c) Lansoprazole sublingual tablet F9.

Table 3. Compositions of sublingual tablets of lansoprazole.

\begin{tabular}{cccccccccccc}
\hline Ingredients (mg) & F1 & F2 & F3 & F4 & F5 & F6 & F7 & F8 & F9 & F10 & F11 \\
\hline Lanso SD (Soluplus) & 45 & 45 & 45 & 45 & 45 & 45 & 45 & 45 & 45 & 45 & 45 \\
Equivalent to 15mg & & & & & & & & & & & \\
$\quad$ Indion - 414 & 3 & 4.5 & 6 & 6 & 7.5 & 7.5 & 7.5 & 9 & 6 & 8 & 4 \\
Kyron T-314 & 3 & 4.5 & 6 & 6 & 7.5 & 7.5 & 7.5 & 9 & 6 & 4 & 8 \\
Avicel pH 102 & 30 & 30 & 30 & 22.5 & 22.5 & 22.5 & 15 & 15 & 10 & 10 & 10 \\
Magnesium stearate & 1.5 & 1.5 & 1.5 & 1.5 & 1.5 & 1.5 & 1.5 & 1.5 & 1 & 1 & 1 \\
$\quad$ Talc & 1.5 & 1.5 & 1.5 & 1.5 & 1.5 & 1.5 & 1.5 & 1.5 & 1 & 1 & 1 \\
Mannitol & 62 & 59 & 56 & 63.5 & 60.5 & 45.5 & 68 & 65 & 28 & 28 & 28 \\
Lactose & - & - & - & - & - & 15 & - & - & - & - & - \\
Sodium saccharin & 4 & 4 & 4 & 4 & 4 & 4 & 4 & 4 & 3 & 3 & 3 \\
Total weight (mg) & 150 & 150 & 150 & 150 & 150 & 150 & 150 & 150 & 100 & 100 & 100 \\
\hline
\end{tabular}

The formulation F4 contains $8 \%$ superdisintegrants but the concentration of avicel was changed in these formulation from 20 to $15 \%$ which found to give further reduction in disintegration time as 46 seconds. The F5 formulation was prepared with 10\% superdisintegrants and 15\% avicel showed promising result as 40 seconds disintegration time.

As per literature, addition of lactose decrease the disintegration time so it was tried in F6 formulation by adding the lactose in combination with mannitol [21]. The results obtained were not satisfying as tablet showed capping during the manufacturing and also, there was increase in disintegration time as 118 seconds. So in further formulations lactose was not added. The F7 formulation with $10 \%$ superdisintegrants and $10 \%$ avicel (binding agent) gave the disintegration time of 36 seconds. The eight formulations (F1 - F8) have a tablet weight of $150 \mathrm{mg}$ therefore in a further formulations attempts were made to reduce the tablet weight from 150 to $100 \mathrm{mg}$. By keeping the solid dispersion concentration same $45 \mathrm{mg}$ the F9 formulation was prepared with same excipient and properties as F8 formulation. It was observed 32 seconds of disintegration time with F9 formulation but with a total blend of $100 \mathrm{mg}$ instead of $150 \mathrm{mg}$. In the F10 and F11 formulations change of proportion of superdisintegrants as 2:1 and 1:2 respectively failed to give further reduction in disintegration time. Thus $12 \%$ of superdisintegrants with $1: 1$ proportion and $10 \%$ binding agent 
(F9) show promising results in disintegration time. From all the above data the formuation F9 showed the rapid disintegration as compared to all other formulations.

\subsection{Evaluation of pre-compression and post-compression parameters of lansoprazole sublingual tablet}

All formulations of lansoprazole sublingual tablet evaluated for pre-compression and postcompression parameters. In the pre-compression parameters powder blend was evaluated for micromeritic properties as discussed below. The pre-compression parameters play an important role in tablet. The angle of repose of powder blend F9 was found to be $28.81^{\circ}$ which is in the range of $25-30^{\circ}$ which indicates excellent flow property [22]. Further it was confirmed with a carr's index which is observed $7.5 \%$ (range is 5 - 10\%) indicates excellent flow property. Hausner's ratio of 1.08 also showed excellent flow property within the acceptable limits. All the pre-compression parameters of all formulations are shown in Table 4.

Table 4. Pre-compression parameters of lansoprazole powder blend.

\begin{tabular}{cccccc}
\hline Formulation & $\begin{array}{c}\text { Angle of } \\
\text { repose } \mathbf{( 0})\end{array}$ & $\begin{array}{c}\text { Bulk density } \\
\mathbf{g m} / \mathbf{m l}\end{array}$ & $\begin{array}{c}\text { Tapped density } \\
\mathbf{g m} / \mathbf{m l}\end{array}$ & $\begin{array}{c}\text { Carr's index } \\
\mathbf{\%}\end{array}$ & Hausner's ratio \\
\hline F1 & $27.77 \pm 0.50$ & $0.35 \pm 0.004$ & $0.39 \pm 0.054$ & $8.9 \pm 0.055$ & $1.10 \pm 0.05$ \\
F2 & $25.54 \pm 0.33$ & $0.34 \pm 0.021$ & $0.38 \pm 0.043$ & $8.5 \pm 0.065$ & $1.09 \pm 0.05$ \\
F3 & $29.89 \pm 0.44$ & $0.36 \pm 0.034$ & $0.39 \pm 0.057$ & $9.1 \pm 0.056$ & $1.12 \pm 0.18$ \\
F4 & $26.13 \pm 0.27$ & $0.38 \pm 0.044$ & $0.41 \pm 0.065$ & $7.2 \pm 0.077$ & $1.05 \pm 0.08$ \\
F5 & $25.94 \pm 0.71$ & $0.35 \pm 0.032$ & $0.39 \pm 0.012$ & $7.9 \pm 0.098$ & $1.14 \pm 0.04$ \\
F6 & $29.44 \pm 0.51$ & $0.39 \pm 0.045$ & $0.42 \pm 0.044$ & $7.8 \pm 0.087$ & $1.04 \pm 0.06$ \\
F7 & $27.65 \pm 0.34$ & $0.33 \pm 0.007$ & $0.37 \pm 0.065$ & $7.7 \pm 0.055$ & $1.13 \pm 0.09$ \\
F8 & $25.55 \pm 0.11$ & $0.34 \pm 0.003$ & $0.38 \pm 0.034$ & $7.6 \pm 0.054$ & $1.05 \pm 0.17$ \\
F9 & $28.81 \pm 0.23$ & $0.37 \pm 0.005$ & $0.40 \pm 0.044$ & $7.5 \pm 0.047$ & $1.08 \pm 0.01$ \\
F10 & $24.76 \pm 0.43$ & $0.34 \pm 0.043$ & $0.36 \pm 0.034$ & $7.4 \pm 0.033$ & $1.04 \pm 0.04$ \\
F11 & $24.98 \pm 0.88$ & $0.38 \pm 0.055$ & $0.43 \pm 0.045$ & $8.2 \pm 0.055$ & $1.14 \pm 0.09$ \\
\hline
\end{tabular}

a All values represents mean $\pm S D(n=3)$.

The drug and excipient compatibility study of formulation F9 batch carried out by DSC and FTIR. The FTIR of powder blend not showed sharp peak because of the mixture of solid dispersion is in amorphous state. There is no chemical reaction between the drug and excipients and no changes seen in drug and carrier. The DSC thermogram of powder blend showed 4 endothermic peaks, first peak is at $70.56^{\circ} \mathrm{C}$ indicates the melting point of carrier and other two peaks are of powder blend and peak at $164.56^{\circ} \mathrm{C}$ indicates peak are broad and shifted to a lower temperature and exothermic peak of drug are disappeared as compared to pure drug peak indicates complete miscibility of drug in a Soluplus or the absence of crystalline form of lansoprazole, means solid dispersion mixture is in amorphous state and indicates no degradation of drug in formulation. The FTIR spectra of lansoprazole sublingual tablet F9 are depicted in Figure 2 and DSC thermogram of lansoprazole sublingual tablet F9 are depicted in Figure 3.

The tablet prepared with above F9 powder blend formulation found to be smooth rounded shape with no any imperfections. This tablet were evaluated for weight variation test. The tablet pass the weight variation test as standard deviation observed was within the $10 \%$ limit. Friability was also found to be less than $1 \%$ which indicates suitability of the tablet for the transportation. Disintegration time with no larger residues was found to be only 32 seconds which confirm its acceptability as a sublingual tablet [22]. The other parameter studied were also in the acceptable range as shown in Table 5.

\subsection{In vitro dissolution studies}

The release of the drug is depends on the disintegration of the tablet i.e. faster the disintegration the release of the drug will be faster. The drug release was found above $11.43 \%$ after 2 minutes. The formulation F1 - F5 released $79.76-92.54 \%$ of drug after 8 minutes. Formulation F6 - F8 released $66.99-95.65 \%$ of drug release after 8 minutes. The formulation F9 released $98.42 \%$ in 8 minutes. It was found that formulation F9 showed faster drug release as compared to other formulations. The formulations F10 and F11 released $90.87 \%$ and $77.99 \%$ of drug after 8 minutes. The in vitro drug release profile of all formulations shown in Figure 4. The release data was fitted in the different kinetic release model which indicates zero order release pattern as shown in Table 6. The release rate and the pattern indicates the suitability of the dosage form for sublingual route. 
Table 5. Post-compression parameters of lansoprazole sublingual tablet.

\begin{tabular}{|c|c|c|c|c|c|c|c|c|}
\hline $\begin{array}{l}\text { Formu } \\
\text { lation }\end{array}$ & $\begin{array}{c}\text { Weight } \\
\text { variation }\end{array}$ & $\begin{array}{c}\text { Thickness } \\
\text { (mm) }\end{array}$ & $\begin{array}{c}\text { Hardness } \\
\left(\mathrm{kg} / \mathrm{cm}^{2}\right)\end{array}$ & $\begin{array}{c}\text { Friability } \\
(\%)\end{array}$ & $\begin{array}{c}\text { Disintegration } \\
\text { time } \\
\text { (Sec) }\end{array}$ & $\begin{array}{l}\text { Wetting } \\
\text { time } \\
\text { (Sec) }\end{array}$ & $\begin{array}{c}\text { Water } \\
\text { absorption } \\
\text { ratio } \\
(\%)\end{array}$ & $\begin{array}{l}\text { Uniformity } \\
\text { of drug } \\
\text { content } \\
(\%)\end{array}$ \\
\hline $\mathrm{F} 1$ & $\begin{array}{c}100.08 \pm \\
0.56\end{array}$ & $3.2 \pm 0.24$ & $2.5 \pm 0.11$ & $\begin{array}{c}0.81 \pm \\
0.77\end{array}$ & $66 \pm 0.82$ & $\begin{array}{l}97 \pm \\
1.49\end{array}$ & $70 \pm 0.11$ & $99.70 \pm 0.67$ \\
\hline $\mathrm{F} 2$ & $\begin{array}{c}101.24 \pm \\
0.77\end{array}$ & $3.1 \pm 0.39$ & $2.7 \pm 0.43$ & $\begin{array}{c}0.56 \pm \\
0.54\end{array}$ & $58 \pm 1.21$ & $\begin{array}{l}91 \pm \\
0.56\end{array}$ & $74 \pm 1.99$ & $98.43 \pm 0.99$ \\
\hline F3 & $\begin{array}{c}100.48 \pm \\
0.45\end{array}$ & $3.0 \pm 0.22$ & $2.6 \pm 0.65$ & $\begin{array}{c}0.49 \pm \\
0.87\end{array}$ & $52 \pm 0.97$ & $\begin{array}{l}85 \pm \\
0.44\end{array}$ & $77 \pm 0.65$ & $97.77 \pm 0.32$ \\
\hline $\mathrm{F} 4$ & $\begin{array}{c}99.98 \pm \\
0.43\end{array}$ & $3.2 \pm 0.61$ & $2.5 \pm 0.65$ & $\begin{array}{c}0.44 \pm \\
0.98\end{array}$ & $47 \pm 0.73$ & $\begin{array}{l}81 \pm \\
0.67\end{array}$ & $78 \pm 1.43$ & $99.43 \pm 0.66$ \\
\hline F5 & $\begin{array}{c}100.34 \pm \\
0.99\end{array}$ & $3.3 \pm 0.68$ & $2.6 \pm 0.99$ & $\begin{array}{c}0.48 \pm \\
0.76\end{array}$ & $40 \pm 0.98$ & $\begin{array}{l}80 \pm \\
0.99\end{array}$ & $75 \pm 0.66$ & $98.11 \pm 0.21$ \\
\hline F6 & $\begin{array}{c}99.98 \pm \\
0.89\end{array}$ & $3.2 \pm 0.62$ & $2.5 \pm 0.65$ & $\begin{array}{c}0.41 \pm \\
0.33\end{array}$ & $118 \pm 0.53$ & $\begin{array}{c}141 \pm \\
0.11\end{array}$ & $59 \pm 1.65$ & $97.33 \pm 0.99$ \\
\hline F7 & $\begin{array}{c}99.87 \pm \\
0.43\end{array}$ & $3.1 \pm 0.66$ & $2.5 \pm 0.55$ & $\begin{array}{c}0.67 \pm \\
0.88\end{array}$ & $36 \pm 0.88$ & $\begin{array}{l}48 \pm \\
0.54\end{array}$ & $78 \pm 0.99$ & $98.99 \pm 0.23$ \\
\hline F8 & $\begin{array}{c}100.70 \pm \\
0.99\end{array}$ & $3.1 \pm 0.45$ & $2.6 \pm 0.78$ & $\begin{array}{c}0.52 \pm \\
0.77\end{array}$ & $35 \pm 1.02$ & $\begin{array}{l}45 \pm \\
0.99\end{array}$ & $79 \pm 0.43$ & $98.66 \pm 0.99$ \\
\hline F9 & $\begin{array}{c}99.25 \pm \\
0.87\end{array}$ & $3.1 \pm 0.25$ & $2.6 \pm 0.06$ & $\begin{array}{c}0.50 \pm \\
0.56\end{array}$ & $32 \pm 1.01$ & $\begin{array}{l}41 \pm \\
1.50\end{array}$ & $81 \pm 1.58$ & $99.53 \pm 0.09$ \\
\hline F10 & $\begin{array}{c}100.69 \pm \\
0.98\end{array}$ & $3.0 \pm 0.32$ & $2.7 \pm 0.44$ & $\begin{array}{c}0.43 \pm \\
0.55\end{array}$ & $35 \pm 1.09$ & $\begin{array}{l}47 \pm \\
0.33\end{array}$ & $80 \pm 0.33$ & $99.67 \pm 0.43$ \\
\hline F11 & $\begin{array}{c}101 \pm \\
0.99\end{array}$ & 3.20 .33 & $2.5 \pm 0.99$ & $\begin{array}{c}0.45 \pm \\
0.70\end{array}$ & $40 \pm 1.33$ & $\begin{array}{l}49 \pm \\
0.76\end{array}$ & $79 \pm 0.66$ & $98.76 \pm 0.11$ \\
\hline
\end{tabular}

a All values represents mean $\pm S D(n=3)$.

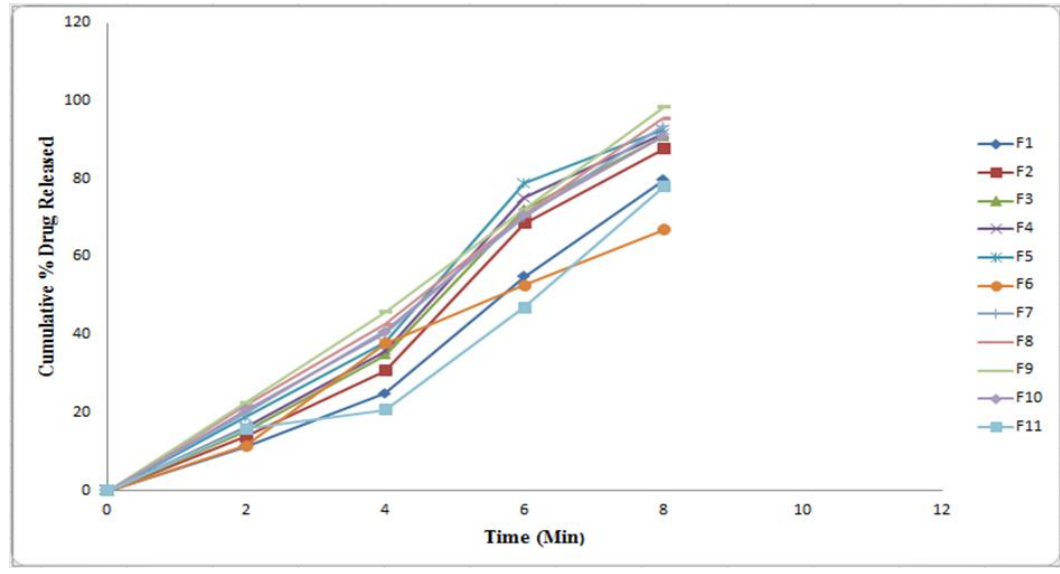

Figure 4. In vitro drug release profile of lansoprazole sublingual tablet.

Table 6. Kinetic study of lansoprazole sublingual tablet.

\begin{tabular}{ccccc}
\hline \multirow{2}{*}{$\begin{array}{c}\text { Formulation } \\
\text { Code }\end{array}$} & \multicolumn{4}{c}{ Release Kinetics } \\
\cline { 2 - 5 } & $\begin{array}{c}\text { Zero order } \\
\mathbf{R}^{\mathbf{2}}\end{array}$ & $\begin{array}{c}\text { First order } \\
\mathbf{R}^{\mathbf{2}}\end{array}$ & $\begin{array}{c}\text { Higuchi } \\
\mathbf{R}^{\mathbf{2}}\end{array}$ & $\begin{array}{c}\text { Peppas } \\
\mathbf{R}^{\mathbf{2}}\end{array}$ \\
\hline F1 & 0.990 & 0.954 & 0.965 & 0.965 \\
F2 & 0.990 & 0.958 & 0.961 & 0.959 \\
F3 & 0.991 & 0.962 & 0.960 & 0.945 \\
F4 & 0.989 & 0.965 & 0.958 & 0.944 \\
F5 & 0.992 & 0.858 & 0.973 & 0.946 \\
F6 & 0.989 & 0.895 & 0.968 & 0.949 \\
F7 & 0.995 & 0.919 & 0.966 & 0.948 \\
F8 & 0.994 & 0.931 & 0.965 & 0.943 \\
F9 & 0.998 & 0.943 & 0.977 & 0.948 \\
F10 & 0.993 & 0.889 & 0.961 & 0.942 \\
F11 & 0.992 & 0.890 & 0.962 & 0.944 \\
\hline
\end{tabular}




\subsection{Accelerated stability study}

Stability study of lansoprazole sublingual tablet F9 was carried out to determine the effect of presence of formulation additives on the stability of the drug and also to determine the physical stability of the formulation under accelerated storage conditions. Stability study was carried out at $40 \pm 20^{\circ} \mathrm{C} / 75 \pm 5 \% \mathrm{RH}$ for 90 days showed no significant change in the lansoprazole sublingual tablet. Evaluations are shown in Table 7. From these stability data it was confirmed that formulation is stable with minor changes [22].

Table 7. Stability study of lansoprazole sublingual tablet F9.

\begin{tabular}{lcc}
\hline Parameters & Initial & After 3 months \\
\hline Appearance & White buff color & White buff color \\
Disintegration time & $32 \pm 1.01$ & $33 \pm 0.70$ \\
Hardness & $2.6 \pm 0.006$ & $2.7 \pm 0.12$ \\
Cumulative \% drug released & $98.42 \pm 0.74$ & $97.89 \pm 0.57$ \\
\hline
\end{tabular}

a All values represents mean $\pm S D(n=3)$.

\section{CONCLUSION}

The present study have proved that solubility enhancement of poorly aqueous soluble drug lansoprazole was possible by preparing the solid dispersion with amphiphilic carrier Soluplus by using solvent evaporation method, solvent melting method and microwave oven method. From the various lansoprazole solid dispersions, the solid dispersion prepared with Soluplus in the concentration 1:2 by solvent melting method have exhibited the enhanced solubility in contrast to other solid dispersions. Lansoprazole sublingual tablet formulated using selected solid dispersion with combination of Indion - 414 and Kyron T - 314 superdisintegrants have shown rapid disintegration in average 32 seconds and cumulative drug release was found to be $98.42 \%$ in $8 \mathrm{~min}$ which indicates zero order release pattern. It was found that lansoprazole sublingual tablet formulated using solid dispersion with Soluplus and superdisintegrants Indion - 414 and Kyron T - 314 are novel and best for enhancing disintegration and for improving dissolution rate. This formulation which reduces the production cost because of in this formulation enteric coating is not required. The lansoprazole sublingual tablet may be beneficial and convenient for pediatrics, geriatrics, and psychiatric patients and patients with swallowing difficulties and in situations where water is not available. This patient friendly dosage form will give quick on set of action.

\section{MATERIALS AND METHODS}

Lansoprazole received as a gift sample from Cipla Ltd. Verna, Goa and Soluplus commercially purchased from Yarrow Chem Product Dombivali (E) Mumbai. Indion - 414 received as a gift sample from Ion Exchange Ltd, Ankleshwar. Kyron T - 314 received as a gift sample from Corel Pharma Chem, Ahmedabad. Avicel pH 102, Magnesium Stearate, Talc, D-Mannitol, Sodium Saccharin obtained from Research-Lab Fine Chem Industries, Mumbai.

\subsection{Preparation of calibration curve of lansoprazole}

The stock solution of lansoprazole, prepared by about $10 \mathrm{mg}$ of lansoprazole was accurately weighed and dissolved in $100 \mathrm{ml}$ of methanol to obtain a concentration $100 \mu \mathrm{g} / \mathrm{ml}$. From stock solution different aliquots were taken in series of 1, 2, 3, 4, $5 \mathrm{ml}$ in $10 \mathrm{ml}$ volumetric flask and diluted with water to obtain a series of concentration. The solutions were scanned in spectrophotometer in UV range $200-400 \mathrm{~nm}$. The absorption maxima of lansoprazole was found to be $284 \mathrm{~nm}$. The standard curve was plotted and values of slope, intercept and coefficient of correlation were calculated [23].

\subsection{Solubility study of lansoprazole}

An excess amount of lansoprazole was added in different conical flasks containing $10 \mathrm{ml}$ different media closed appropriately and placed in REMI incubator shaker for 24 hours at $50 \mathrm{rpm}$ at $37^{\circ} \mathrm{C}$ then removed and filtered using whatmann filter paper. A clear solution was obtained, diluted suitably with appropriate media and absorbance were measured at $284 \mathrm{~nm}$ by using respected dissolution media as a blank solution $[14,15]$. 


\subsection{Preparation of solid dispersion of lansoprazole}

The physical mixtures of lansoprazole with amphiphilic carrier Soluplus in the concentration ratio of 1:2 were prepared by solvent evaporation method, solvent melting method and microwave oven method.

\subsubsection{Solvent evaporation method}

In this technique, required quantity of lansoprazole and carriers are added to a sufficient amount of methanol to dissolve and transferred into china dish, then solvent is heated to evaporate which forms dried mixture. Then these resultant mixture was powdered in mortar, passed through the sieve no. 80 and stored in well closed amber colored container [24].

\subsubsection{Solvent melting method}

In this technique, required quantity of lansoprazole was dissolved in sufficient amount of methanol, solution was prepared and required quantity of carrier was melted in china dish at temperature $60-80^{\circ} \mathrm{C}$. Then in this molten carrier, lansoprazole dissolved methanol solution are added and mixed with glass rod for $15 \mathrm{~min}$. After that china dish is allowed to deep freeze at $-70^{\circ} \mathrm{C}$ for 24 hours. Then these mixture was cooled and solvent free film is formed. The solidified mixture was powdered in mortar, passed through sieve no. 80 and stored in well closed amber colored glass container [25].

\subsubsection{Microwave oven method}

In this technique, required amount of drug and carrier was mixed together in mortar pestle to form a mixture, in this mixture $1 \mathrm{ml}$ of water is added to form a homogeneous slurry, this slurry is transferred in petri plate with teflon stirrer then placed in microwave and treated for different time such as 2, 3, 4, 5 min at power of $560 \mathrm{~W}$. After that the petri plate was removed and placed at room temperature for solidification, these formed dried mixture was powdered in mortar, passed through sieve no. 80 and stored in well closed amber colored glass container [26].

\subsection{Solubility determination of lansoprazole solid dispersion}

An excess amount of lansoprazole solid dispersion was added in different conical flasks containing 10 $\mathrm{ml}$ different media closed appropriately and placed in REMI incubator shaker for 24 hours at $50 \mathrm{rpm}$ at $37^{\circ} \mathrm{C}$ then removed and filtered using whatmann filter paper. A clear solution was obtained, diluted suitably with appropriate media and absorbance were measured at $284 \mathrm{~nm}$ by using respected dissolution media as a blank solution [15].

\subsection{Characterization of lansoprazole solid dispersion}

The selected solid dispersion was evaluated for drug excipient compatibility by FTIR (Shimadzu) analysis and DSC (Mettler Toledo, Mumbai) analysis. The FTIR spectra of lansoprazole solid dispersion was obtained by potassium bromide (KBr) method and scanning the powder in the range of $4000-400 \mathrm{~cm}^{-1}$ and the resolution was $1 \mathrm{~cm}^{-1}$ [16]. The DSC thermogram of lansoprazole solid dispersion was obtained by heating the powder to a scanning rate $10^{\circ} \mathrm{C} / \mathrm{min}$ from $30^{\circ} \mathrm{C}$ to $350^{\circ} \mathrm{C}$ for solid dispersion as well as plane drug [17].

\subsection{Formulation and evaluation of sublingual tablet of lansoprazole solid dispersion}

The formulation of sublingual tablet of lansoprazole was done by using selected solid dispersion mixture with diferent combination of Indion - 414 and Kyron T - 314. The effect of concentration of binding agent was also studied simultaneously. Tablets were prepared by direct compression method using mannitol as a diluent, Lactose is also diluent tried in combination with mannitol in one of the formulation. Attempts were done to reduce the weight of the tablet from 150 to $100 \mathrm{mg}$ for more comfortable administration. The composition of different formulation batches are shown in Table 3. All the material was precisely weighed, except magnesium stearate other materials transferred to mortar, mixed and passed through a sieve no 60 . The lubrication was done by adding the magnesium stearate into powder blend and mixed for 3 minutes. Then the blend of powder were immediately compressed into the tablet by a rotary mini-press tablet punching machine [27]. The weight of tablet is $150 \mathrm{mg}$ for formulation F1 to F8 and $100 \mathrm{mg}$ for F9 to F11. The formulated tablets were evaluated for disintegration time, which was measured by about 6 $-8 \mathrm{ml}$ of water was taken in $10 \mathrm{ml}$ of measuring cylinder. Tablet was placed in the cylinder and time required for complete disintegration was measured [28]. 


\subsection{Evaluation of pre-compression and post-compression parameters of lansoprazole sublingual tablet}

Based on the disintegration time study the formulation F9 gave faster disintegration as compared to all other formulations as 32 seconds. Then all the formulations were evaluated for pre-compression and postcompression parameters [22].

The powder blend of F1 - F11 formulations was evaluated for pre-compression parameters as below:

\subsubsection{Angle of repose}

It was carried out by passing the powder blend slowly through the funnel fixed at a height of $2 \mathrm{~cm}$ over the plane surface, pile was formed. Around the pile a circle was drawn and radius of powder was measured [22]. Then angle of repose calculated from the following formula (Equation 1):

$\theta=\tan -1(h / r)$

where, $\theta=$ angle of repose, $\mathrm{h}=$ height of pile, $\mathrm{r}=$ average radius of the powder cone.

\subsubsection{Bulk density}

It was carried out by pouring powder blend in $100 \mathrm{ml}$ graduated cylinder. The sample occupied volume has been recorded. Bulk density were calculated by following formula (Equation 2):

Bulk density $(\mathrm{g} / \mathrm{ml})=\frac{\text { weight of sample }}{\text { volume occupied by sample }}$

\subsubsection{Tapped density}

It was carried out by pouring the powder blend which was then tapped in tapped density apparatus for 1 minute. After that tapped volume was recorded and tapped density was calculated by using following formula (Equation 3):

$$
\text { Tapped density }(\mathrm{g} / \mathrm{ml})=\frac{\text { weight of sample }}{\text { Tapped volume }}
$$

\subsubsection{Hausner's ratio}

For the determination of flow property, hausner's ratio calculated by using tapped density and bulk density as below (Equation 4):

$$
\text { Hausner's ratio }=\frac{\text { Tapped density }}{\text { Bulk density }}
$$

\subsection{5. \% Compressibility index}

It was one of the simple technique to determine flow property of powder. In which the bulk density and tapped density was compared and \% Compressibility index was calculated from following formula (Equation 5).

$$
\text { Carrs index }=\frac{\text { Tapped density-Bulk density }}{\text { Tapped density }} \times 100
$$

\subsubsection{Compatibility study}

The compatibility study of powder blend was carried out by FTIR (Shimadzu) and DSC (Mettler Toledo, Mumbai). The powder is observed by FTIR spectrum for color change and chemical change. The FTIR spectra of powder blend was obtained by potassium bromide $(\mathrm{KBr})$ method and scanning the powder in the range of $4000-400 \mathrm{~cm}^{-1}$ and the resolution was $1 \mathrm{~cm}^{-1}$ [16]. The DSC thermogram of powder blend was obtained by powder was heated in DSC to a scanning rate $10^{\circ} \mathrm{C} / \mathrm{min}$ from $30^{\circ} \mathrm{C}$ to $350^{\circ} \mathrm{C}$ [17]. 
The tablets of F9 formulation prepared by using rotary minipress tablet punching machine were evaluated for post-compression parameters as below:

\subsubsection{Weight variation test}

This method is carried out according to Indian pharmacopoeia. Twenty tablets were taken for individual weighing and weighed, then average weight was calculated. Then the percent deviation of tablet was calculated from average weight of the tablet.

\subsubsection{Hardness test}

Monsanto hardness tester was used to measure hardness of the tablet. In which the tablet that was placed in the tester and pressure needed to break the tablet was measured.

\subsubsection{Thickness}

Thickness of tablet was measured by vernier caliper.

\subsubsection{Friability test}

It was carried out by using Roch friability apparatus, in which the accurately weighed 20 tablets was allowed to rolling and free fall, after 100 revolutions weight of tablet was again measured and friability was calculated by following formula (Equation 6).

$$
\% \text { Friability }=\frac{\text { Initial weight of tablet-Final weight of tablet }}{\text { Initial weight of tablet }} \times 100
$$

\subsubsection{Disintegration time test}

The disintegration time were measured by placing the tablet in the disintegration testing apparatus tubes and recording the time required to tablet disintegrate completely [28].

\subsubsection{Wetting time test}

In that the tissue paper has been folded twicely and placed in petri dish above that tablet is placed and $10 \mathrm{ml}$ distilled water was added. The time required to get the tablet completely wet was measured.

\subsubsection{Water absoption ratio}

In this method, the tablet weight was taken and tablet placed in petri dish contains folded tissue paper. In that $10 \mathrm{ml}$ water was added and allowed to tablet complete wet. The wetted tablet is then weighed and absorption ratio calculated by following formula.

$$
\text { Water absorption ratio }=\frac{\mathrm{Wa}-\mathrm{Wb}}{\mathrm{Wb}} \times 100
$$

Where, $\mathrm{Wa}$ - weight of tablet after absorption \& $\mathrm{Wb}$ - weight of tablet before absorption.

\subsubsection{Uniformity of drug content}

This method is performed as per Indian Pharmacopoeia. Two tablets were crushed and added to 30 $\mathrm{ml}$ of $0.1 \mathrm{M} \mathrm{NaOH}$ in $100 \mathrm{ml}$ volumetric flask sonicated to disintegrate, then diluted by acetonitrile and then these solution was filtered and diluted the filterate with a mixture of seven volumes acetonitrile and three volumes of $0.1 \mathrm{M} \mathrm{NaOH}$. Absorbance was measured by UV spectroscopy at 284nm [29].

\subsubsection{In vitro dissolution studies}

The dissolution study of lansoprazole sublingual tablet F9 was conducted by using USP dissolution apparatus Type - II (Electrolab Mumbai) by taking $900 \mathrm{ml}$ phosphate buffer $\mathrm{pH} 6.8$ as dissolution medium which maintained at $37 \pm 0.5^{\circ} \mathrm{C}$. At every 2 min interval upto $10 \mathrm{~min} 5 \mathrm{ml}$ samples was withdrawn and the same volume was replaced to maintain the sink condition. The samples were analysed using UV spectroscopy at wavelength maxima $284 \mathrm{~nm}$. 


\subsubsection{Accelerated stability study lansoprazole sublingual tablet}

The stability study of lansoprazole sublingual tablet F9 was conducted by storing the tablets in an aluminium foil and subjected to elevated temperature and humidity conditions of $40 \pm 20^{\circ} \mathrm{C} / 75 \pm 5 \% \mathrm{RH}$ for three months and were withdrawn at the end of 30,60 and 90 days and evaluated for appearance, hardness, disintegration time and in vitro drug release [22].

Acknowledgements: Authors are thankful to Dr. R.Y.Patil, Principal, Seth Govind Raghunath Sable College of Pharmacy, Saswad for providing necessary facilities to carry out the research work.

Author contributions: Concept - V.S., S.M.; Design - V.S., S.M.; Supervision - S.M.; Resources - S.M.; Materials - V.S, S.M.; Data Collection and/or Processing - V.S., S.M.; Analysis and/or Interpretation - S.M., V.S.; Literature Search V.S., S.M.; Writing - V.S.; Critical Reviews - S.M., V.S.

Conflict of interest statement: We wish to confirm that there are no known conflicts of interest associated with this publication and there has been no significant financial support for this work that could have influenced its outcome.

\section{REFERENCES}

[1] Garnett WR. Formulary forum lansoprazole : a proton pump inidbitor. Ann Pharmacother. 1996; 30(12): 1425-1436. [CrossRef]

[2] Matheson AJ, Jarvis B. Lansoprazole: an update of its place in the management of acid-related disorders. Drugs. 2001; 61(12): 1801-1833. [CrossRef]

[3] Richter JE, Kahrilas PJ, Sontag SJ, Kovacs TOG, Huang B, Pencyla JL. Comparing lansoprazole and omeprazole in onset of heartburn relief: results of a randomized, controlled trial in erosive esophagitis patients. Am J Gastroenterol. 2001; 96(11): 3089-3098. [CrossRef]

[4] Population S. Lansoprazole for the prevention of recurrences of ulcer complicatons from long-term low-dose asprin use. N Engl J Med. 2002; 346(26): 2033-2038. [CrossRef]

[5] Malfertheiner P, Mégraud F, O'Morain C, Hungin APS, Jones R, Axon A, Graham DY, Tatya G. Current concepts in the management of helicobacter pylori infection - the maastricht 2-2000 consensus report. Aliment Pharmacol Ther. 2002; 16(2): 167-180. [CrossRef]

[6] Tolman KG, Sanders SW, Buchi KN, Karol MD, Jennings DE, Ringham GL. The effects of oral doses of lansoprazole and omeprazole on gastric ph. J Clin Gastroenterol. 1997; 24(2): 65-70. [CrossRef]

[7] Bind AK, Gnanarajan G, Kothiyal P. A review: sublingual route for systemic drug delivery. Int J Drug Res Tech. 2013; 3(2): 31-36.

[8] El-Samaligy MS, Afifi NN, Mahmoud EA. Increasing bioavailability of silymarin using a buccal liposomal delivery system: preparation and experimental design investigation. Int J Pharm. 2006; 308(1-2): 140-148. [CrossRef]

[9] Pawar PP, Ghorpade HS, Kokane BA. Sublingual route for systemic drug delivery. J Drug Deliv Ther. 2019; 8(6): 340-343. [CrossRef]

[10] Price TM, Blauer KL, Hansen M, Stanczyk F, Lobo R, Bates GW. Single-dose pharmacokinetics of sublingual versus oral administration of micronized 17 $\beta$-estradiol. Obstet Gynecol Surv. 1997; 89(3): 340-345. [CrossRef]

[11] Narang N, Sharma J. Sublingual mucosa as a route for systemic drug delivery. Int J Pharm Pharm Sci. 2011; 3(2): $18-22$.

[12] Singh DH, Roychowdhury S, Varma P, Bhandari V. A review on recent advances of enteric coating. IOSR J Pharm. 2012; 2(6): 05-11.

[13] Nikghalb LA, Singh G, Singh G, Kahkeshan KF. Solid dispersion: methods and polymers to increase the solubility of poorly soluble drugs. J Appl Pharm Sci. 2012; 2(10): 170-175. [CrossRef]

[14] Baka E, Comer JEA, Takács-Novák K. Study of equilibrium solubility measurement by saturation shake flask method using hydrochlorothiazide as model compound. J Pharm Biomed Anal. 2008; 46(2): 335-341. [CrossRef]

[15] Garg T. An approach for improvement of the water solubility of gliclazide in solid dispersion with. Int J Pharm Sci Res. 2011; 2(6): 1600-1602. [CrossRef] 
[16] Lu Y, Guo T, Qi J, Zhang J, Wu W. Enhanced dissolution and stability of lansoprazole by cyclodextrin inclusion complexation: preparation, characterization, and molecular modeling. AAPS PharmSciTech. 2012; 13(4): 1222-1229. [CrossRef]

[17] Patil OA, Patil IS, Mane RU, Randive DS, Bhutkar MA, Bhinge SD. Formulation optimization and evaluation of cefdinir nanosuspension using 23 factorial design. Marmara Pharm J. 2018; 22(4): 587-598. [CrossRef]

[18] Bhagat S, Rodrigues C, Keny RV. Design and development of rapid release mouth disintegrating terbutaline sulphate tablets - a comparative evaluation of superdisintegrants and their combinations. Int J Res Chem. 2014; 4(3): 586-594.

[19] Mohanachandran PS, Sindhumol PG, Kiran TS. Superdisintegrants: an overview. Int J Pharm Sci Rev Res. 2011; 6(1): 105-109.

[20] Sah S, Badola A, Kothiyal P. Sublingual tablets : an overview. Indian J Pharm Biomed Res. 2016; 4(2): $20-26$.

[21] Bookya P, Raparla R, Sriramula S. Formulation and evaluation of fast dissolving tablets of captopril. J Pharm Res. 2014; 8(7): 963-968.

[22] Chaudhari K, Jadhao U, Chaudhari C, Thakare V, Tekade B, Chaudhari C. Formulation and evaluation of fast dissolving sublingual tablets of amlodipine besylate. Der Pharmac Sin. 2014; 5(4): 1-9.

[23] Mohan K, Sai R, Sudheer M, Kumar K, Kumar A, Sekhar R, Nagarjuna S. New uv-spectrophotometric method for the determination of lansoprazole in pharmaceutical dosage form and its application to protein binding study. $\mathrm{J}$ Pharm Res. 2011; 4(6): 1586-1587.

[24] Kavitha R, Sathali AH. Enhancement of solubility of repaglinide by solid dispersion technique. Int J Chem Sci. 2012; 10(1): 377-390.

[25] Neha A, Singh I, Sharma M, Tarun G. An approach for improvement of the water solubility of nimesulide in solid dispersion with peg 4000. IOSR J Pharm. 2012; 2(2): 153-154.

[26] Nasir AS. Jain AM, Bari MM, Chavan RB, Barhate SD. New dimensions to solid dispersion. Indo Am J Pharm Res. 2013; 3(4): 3246-3255.

[27] Kurnool AN, Vijay Kumar BS, Chilkwar RN, Jagdeesha SE. Formulation and evaluation of sublingual drug delivery system containing anti-ulcerative agent. World J Pharm Pharm Sci. 2015; 4(5): 890-899.

[28] Shah NH, Nagar BJ, Sheorey SD, Agrawal V, Shah JM. Formulation and evaluation of orodispersible labetalol tablet for hypertensive crisis. J Drug Deliv Ther. 2013; 3(6): 106-112.

[29] Indian Pharmacopoeia, sixth ed., India 2010.

This is an open access article which is publicly available on our journal's website under Institutional Repository at http://dspace.marmara.edu.tr. 